Türk Dünyası Dil ve Edebiyat Dergisi

Turkish World Journal of Language and Literature

Sayı/Issue: 48 (Güz-Autumn 2019) - Ankara, TÜRKIYE

\author{
Araştırma Makalesi
}

\title{
MANAS DESTANINDA YER ALAN ALMAMBET VE KÜL ÇORO İSIMLI KAHRAMANLAR İLE TARİHTE YAŞAMIŞ TUNYUKUK VE KÜLİ ÇOR ARASINDAKİ BENZERLÍKLER
}

\begin{abstract}
Nurdin USEEV*
Öz

Türk dünyasının bin senelik destan geleneğini, tarihini, kültürünü ve dünya görüşünü kendi içinde barındıran Manas Destanı, Kırgızların ve eski Türk boylarının kültür olgularını, tarihini araştırmada bir sözlü kaynak olma özelliğini taşımaktadır. Köktürk harfli yazıtlar ise Eski Türkler hakkında bilgi edinebileceğimiz yazılı kaynakların başında bulunmaktadır. Bundan dolayı yazıtlar ile Manas Destanı'nı karşılaştırarak incelemek yerinde olacaktır. Makalemizde II. Köktürk Kağanlığı'nın kurulmasında büyük katkısı olan ve hayatları Orhun Yazıtları'nda anlatılan devlet adamları Tunyukuk ve Küli Çor, Manas Destanı'ndaki Almambet ve Kül Çoro ile karşılaştırılmış, bunların arasında dikkat edici benzerliklerin bulunduğu tespit edilmiştir. Örneğin, tarihte yaşayan Küli Çor ile destandaki Kül Çoro'nun isimleri aynı olmakta, üstelik her ikisi hükümdar oğluna atabeylik yapmaktadırlar. Bundan dolayı tarihî bir şahıs olan Küli Çor, Manas Destanı'nda Kül Çoro'nun kişiliğinde izini koruduğu ileri sürülmüştür. Bunun nedeni de IX-X. asırlar arasındaki Eski Türk tarihi ile ilgilidir. Bilindiği gibi 840 yılında Kırgızlar Uygurları bertaraf ederek Merkezi Asya'ya, kutsal Ötüken'e hâkim olmuşlardır. Ancak nüfus sayısının azlığı, Çin'in her zaman uyguladığı iki yüzlü siyaseti ve diğer Türk boylarının Batı'ya doğru kayması sonucunda Moğolistan'a hâkim olamayan
\end{abstract}

Geliș Tarihi: 30.08 .2018

Kabul Tarihi: 22.08 .2019

Makalenin Künyesi:

Useev, N. (2019). "Manas Destanında Yer Alan Almambet ve Kül Çoro İsimli Kahramanlar ile Tarihte Yaşamış Tunyukuk ve Küli Çor Arasındaki Benzerlikler". Türk Dünyası Dil ve Edebiyat Dergisi, 48, 115-138. DOI: 10.24155/tdk.2019.113

Dr. Öğr. Üyesi, Kırgızistan-Türkiye Manas Üniversitesi, Edebiyat Fakültesi, Türkoloji Bölümü, nuruseev@ gmail.com

ORCID ID: 0000-0002-4192-5216 
Manas Destanında Yer Alan Almambet ve Kül Çoro İsimli Kahramanlar ile

Tarihte Yașamıș Tunyukuk ve Küli Çor Arasındaki Benzerlikler

ve bu kutsal topraklar1 920'lerde Kara Kitaylara birakmak zorunda kalan Kırgızlar, tarihte gerçekleştiremedikleri amaçlarını sözlü edebiyat ürününde, Manas Destanı'nda gerçekleştirmişlerdir. Örnek olarak da Köktürk Kağanlığı'nı almışlardır. Çünkü Köktürk Kağanlığı Türk boylarını bir çatı altında birleştiren, ekonomik ve askerî bakımdan zirveye ulaşan ve en önemlisi Çin'i kendi hâkimiyet altına alan bir devletti.

Anahtar sözcükler: Manas Destanı, Orhun Yazıtları, Tunyukuk, Kül Çoro, Köktürkler.

\section{The Similarities Between Almambet and Kül Çoro in the Manas Epic and the Tunyukuk and Küli Çor in the History}

\section{Abstract}

Manas Epic contains a thousand-year epic tradition, history, culture and world view of the Turkic world in itself. Therefore, the Manas Epic can be a source for investigating the cultural phenomena, archaeological finds of the Kyrgyz people and Old Turkic tribes. Almambet and Kül Çoro in the Manas Epic has been compared with Tunyukuk and Küli Çor which are the statesmen who made a great contribution to the establishment of the Turkish Khanate. It has been found that there are gradual similarities in the between of these. For example, the names of Küli Çor who lived in history and Kül Çoro in the Manas Epic are the same, and both of them are clerics for the son of the ruler. Therefore, it is claimed that the historical person Küli Çor preserved the traces in the personality of the Kül Çoro in the Manas Epic. The reason for this is related to the history of the Old Turkish between the IX- $\mathrm{X}^{\text {th }}$ centuries. As it is known, in 840, the Kyrgyzs ruled Central Asia and the holy Ötüken by eliminating the Uighurs. However, due to the small number of the population, China's two-sided politics and the shift of other Turkish tribes towards the West, the Kyrgyz did not dominate Mongolia and had to leave these holy lands to the Kara Kytais in the 920s. They expressed their aims which they could not realize in history in oral literature, in Manas Epic. They took Köktürk Khanate as an example. Because the Köktürk Khaganate was a state that united the Turkish tribes under one roof, reached the summit in economic and military terms, and most importantly took China under its rule.

Keywords: Manas Epic, Orkhon Inscriptions, Tunyukuk, Kül Çoro, Old Turks.

\section{Giriş}

Manas Destanı ile Türk dünyasının en eski ve en değerli kültürel değeri olan Köktürk harfli yazıtlar arasında önemli benzerlikler bulunmaktadır. $\mathrm{Bu}$ durum destanı araştıran bütün bilim adamlarının dikkatini çekmiştir. Örneğin, P. A. Falev, 'Kak Stroitsya Kara-Kirgizskaya Bılina' adlı maka- 
lesinde destanın giriş formeli ile Köl Tigin Yazıtı'nın başlangıç metninin benzerliği üzerinde durarak Manas Destanı ile Orhun Yazıtları'nı karşılaştırmalı yöntemle incelemek gerektiğini vurgulamaktadır (Falev, 1968: 50). Manas Destanı'nın araştırılmasında, yayımlanmasında ve en önemlisi 1950 yıllarında Sovyet ideolojisinin baskısından kurtulmasında çok emeği geçen M. Auezov, 'O Vremeni Vozniknoveniya Eposa 'Manas' adlı çalışmasında Manas Destanı ile Orhun Yazıtları'nın savaş sahneleri, ağıtlar, epitetler, formeller gibi içerik benzerliklerine dikkat ederek şöyle bir sonuç çıkarmaktadır: 'Bütün bunların sonucunda Manas Destanı'nın metinlerini Eski Türk yazıtlarıyla karşılaştırarak incelemenin çok önemli ve gerekli olduğunu görürüz.' (Auezov, 1995: 156).

Bilindiği gibi Orhun Yazıtları'ndaki şahıslar tarihte yaşayan, II. Köktürk Kağanlığı'nın kurulmasında ve gelişmesinde büyük katkıları olan, hayatları ve kahramanlıkları söz konusu yazıtlarda anlatılan gerçek insanlardır. Destan kahramanları ise kendisinde milletin ideal kahraman tipini barındıran kurmaca şahıslardır. Ancak büyük destanlardaki bazı önemli kahramanların tarihte prototiplerinin olduğu bir gerçektir. Örneğin, A. B. Ercilasun, Dede Korkut Destanı'ndaki Salur Kazan'ın tarihteki karşılığının Türgiş kağanlarından Sulu Kagan olduğunu ileri sürmektedir (Ercilasun, 2002: 22-23). Bunun gibi Manas Destanı'ndaki bazı kahramanların özelliklerini, adlarını Orhun Yazıtları'ndan bulmak mümkündür. Destan kahramanlarının prototiplerini bulmak destan çalışmalarının, folkloristiğin çok büyük meselelerindendir. Çünkü tarihî şahıslar ile destan kahramanlarının ortasındaki ilişki çok karmaşıktır. Bazen tarihte yaşayan gerçek bir şahıs destandaki bir kahramana prototip olup yeni bir kahramanın ortaya çıkmasına vesile olurken (Yıldız, 2015: 505), bazen destandaki kurmaca bir kahraman tarihteki bir şahısa benzetilerek yeniden yapılandırılmakta, tarihî şahıslar destanın içeriğine göre değiştirilmektedir (Putilov, 1971: 64; Jirmunskiy, 1995: 111). Biz de destan kahramanlarının tarihteki izini, prototiplerini tespit etmenin çok zor ve tahminî olduğunu dikkate alarak Manas Destanı'ndaki bazı kahramanlar ile Orhun Yazıtları'ndaki tarihî şahısların ortasındaki benzerlikler üzerinde durmayı uygun gördük. Çünkü bilim adamlarının çoğunluğu Manas Destanı'nın VII-X. asırlar arasındaki Eski Türk devrinde oluştuğunu ve bu devri yansıttığını düşünmektedirler. Bu konuda A. Bakirov, 'VI-X. asırlarda Sibirya'nın güneyinde gerçekleşen büyük olayları tasvir eden Orhun-Yenisey Yazıtları, yeni destanların ortaya çıkmasına vesile olan bu devrin özelliklerini araştırmak için çok değerli kaynaktır', P. A. Troyakov da 'Üstelik Orhun-Yenisey Yazıtları folkloristikteki tarihî-kahramanlık geleneğinin VI-X. asırlarda Sibirya'nın güneyinde gerçekleşen büyük tarihî olaylarla ilişkili olduğunu göstermektedir' demektedirler (Bakirov, 1997: 68; Troyakov, 1983: 77). 
Manas Destanında Yer Alan Almambet ve Kül Çoro Ísimli Kahramanlar ile

Tarihte Yașamıș Tunyukuk ve Küli Çor Arasındaki Benzerlikler

Makalemizde Manas Destanı'nın klasik varyantları olarak kabul edilen S. Orozbakov, S. Karalaev ve C. Mamay varyantları kullanılmıştır. Çünkü bu varyantlar diğerlerine göre daha hacimli olup, tarihî ve kültürel bilgileri daha çok içermektedir. Üstelik Almambet' in hayatı, kişiliği ve kahramanl1$\breve{g}_{1} \mathrm{~S}$. Orozbakov varyantında özel bir yer alıp, geniş ve ayrıntılı bir şekilde anlatılmaktadır (Aalieva vd. 2015: 115). Burada üzerinde durulması gereken bir durum vardır. Bilindiği gibi S. Orozbakov, Arap yazısını bilen, Çağatayca kitapları okuyarak söylediği Manas'a bazı kitap bilgilerini sokan aydın bir kişidir. Ancak bu söylenenler Şah Name vd. gibi Doğu kaynakları için geçerlidir. Rusça, Almanca gibi Batı kaynaklarını kullandığını söylemek yanlıştır. Çünkü o, bu dillere hâkim değildi. Bazı bilim adamları, S. Orozbakov varyantındaki tarihî bilgileri, özellikle Eski Türk tarihiyle ilişkili bilgileri kitaplardan edinilen bilgiler olarak görmektedirler. Örneğin, V. Jirmunskiy, S. Orozbakov'un K. Tinıstanov, İ. Arabaev, B. Soltonoev gibi ‘bilim adamı’ danışmanlarının olduğunu, Eski Türklerle, Orhun Yazıtları'yla ilgili bilgileri işte bu kişiler öğrettiğini belirtmektedir (Jirmunskiy, 1995: 149). Bu görüş yanlış bilgilerden kaynaklanan bir görüştür çünkü 1930'larda Sovyetler Birliği'nde, onun içinde Kırgızistan'da Pantürkistlerden, Panislamistlerden, eskicilerden oluşan 'halk düşmanlarını' temizleme kampanyası yürütülmüştür. İşte bu kampanya sırasında yazarlar, bilim adamları birbirine iftira atarak değişik suçlamalarda bulunmuşlardır. Bundan Manas Destanı'nı derleyenler de, manasçılar da olumsuz yönden etkilenmiştir. Örneğin, K. Malikov, 1937 yılında yayımladığı bir makalesinde K. Tınıstanov, İ. Arabaev gibi şahısları, özellikle K. Tınıstanov'u kötülemek için, adı geçen insanlar, S. Orozbakov'a din, Pantürkizm ile ilgili bilgileri söyleyerek destana eklettiklerini ileri sürmüştür (Bakçiev, 2014: 399). Oysa, gerçek böyle değildir çünkü S. Orozbakov, K. Tınıstanov ve İ. Arabaev ile hayatında bir defa Taşkent'te görüşmüş, çok kısa süren bu görüşmede fikir alışverişinde bulunmamışlardır. Tam tersine bu görüşmeden sonra S. Orozbakov'un morali bozularak dönmüştür. Çünkü K. Tinıstanov, S. Orozbakov'a söylediği Manas'ın dilinin Özbekçeye benzediğini söyleyerek tenkit etmiş İ. Arabaev, Manas'ı yazma işini çabuk bitirmesini talep ederek aksi durumda mahkemeye vereceğini söyleyip tehdit etmiştir. Kendisinden yaşça çok küçük olan bu kişilerden tenkit ve tehdit duyan S. Orozbakov, Kırgızistan'a döndüğünde destanın kalan kısmını çok kısa söyleyip tamamlamaya çalışmıştır. Bu bilgileri bizzat S. Orozbakov ile birlikte bu görüşmelere katılan, onun söylediği destanı yazıya geçiren I. Abdrahmanov vermektedir (Abdrahmanov, 1992: 69-70). Dolayısıyla S. Orozbakov'un K. Tinıstanov, İ. Arabaev, B. Soltonoev gibi 'bilim adamı' danışmanlarının olduğu ve Eski Türklerle, Orhun Yazıtları'yla ilgili verileri bu kişilerden öğrendiği bilgisi siyasi bir iftiradan kaynaklanan yan- 
lış bir görüştür. Bize göre Manas Destanı eski Türk tarihinin, kültürünün bazı unsurlarını kendisinde barındıran, dolayısıyla Orhun-Yenisey Yazıtları'ndaki bilgilerle örtüşen tarihî olayları, kültür olgularını da koruyan bir destandır. Bundan dolayı S. Orozbakov varyantında Orhun Yazıtları'nda türbe, anıt anlamında bulunan ancak günümüz Kırgız Türkçesinde kullanılmayan bark kelimesi aynı anlamda geçmekte ve Manas Destanı'ndaki ölü gömme, türbe yaptırma geleneği eski Türk mezarlık geleneği ile aynen örtüşmektedir (Useev, 2016: 173-191).

Manas Destanı'nın bazı varyantlarında S. Orozbakov, S. Karalaev ve C. Mamay varyantlarında bulunmayan ya da o varyantlara uymayan bilgiler de mevcuttur. Örneğin, W. Radloff tarafindan yazıya geçirilen varyantta Kül Çoro Almambet'in değil, Acıbay'ın oğludur. Ancak S. Karalaev ve C. Mamay varyantlarında Kül Çoro Almambet'in oğludur. Belirtmemiz gereken husus, Manas Destanı'nın W. Radloff tarafından yazıya geçirilen varyantı yazıya geçirilmiş ilk varyant olarak çok değerli olmasına rağmen, muhtevası, olay örgüsü, kapsadığı kültürel ve tarihî bilgiler açısından S. Karalaev, S. Orozbakov ve C. Mamay varyantlarına göre çok düşük seviyedeki bir varyanttır. Bundan dolayı söz konusu varyanta dayanarak destanın muhtevasını, amacını ve tarihî değerini tespit etmeye çalışmak yeterli değildir. Örneğin, destanın bu varyantından yararlanan E. Karabacak, Manas Destanı'nda büyük bir devlet kurma idealinin tam anlamıyla görünmediğini, Manas, sık sık akın yapacağı ülkelerden, atlardan ve kızlardan söz ettiğini ancak toprak alma ve iline katma isteğinin görülmediğini belirtmektedir (Karabacak, 1995: 199). Oysa destanın S. Orozbakov, S. Karalaev ve C. Mamay gibi klasik varyantlarında Manas'ın asıl amac1 halkını özgürlüğe kavuşturmak, eski vatanını geri almak ve dağınık boyları birleştirerek bütün bir devlet kurmaktır.

\section{Tunyukuk ve Almambet}

Tarihte büyük bir iz bırakan insanlar başarılarına tek başlarına değil etraflarına topladığı fikir ve savaş arkadaşlarıyla ulaşmıştır. Bunun gibi Manas Destanı'nın ana kahramanı olan Manas'a en büyük desteği danışmanı olan Bakay, başında Kırgıl bulunan kırk çorosu ve en yakın arkadaş1 Almambet vermiştir. Bunun en güzel kanıtı Almambet gelmeden önce Manas'ın rüya görmesi, bu rüyanın da Acıbay tarafından yorumlanmasıdır. Manas, söz konusu rüyasında şunları görür; bir yere giderken meyvesi bol yere denk gelir. Yolda yürürken altın ve bakırdan yapılan keskin bir kılıç bulur. O kılıcı denemek için taşa vurur. Taş da et gibi kesilir. Kılıcı kınına koyar. Bir süre sonra kılıç kaplana döner. Birçok avı elde eder. Bir tepeye çıkıp haykırınca bütün hayvanlar gelip Manas'a secde eder. Daha sonra kaplan, tuyguna (kartalın bir çeşidi) döner. Bütün kuşlar gelip Manas'a 
Manas Destanında Yer Alan Almambet ve Kül Çoro Ísimli Kahramanlar ile

Tarihte Yașamıș Tunyukuk ve Küli Çor Arasındaki Benzerlikler

secde eder. Manas, bu rüyasını yorumlamalarını ister. Rüyasını da bilgeliği, hatipliği ile meşhur olan çorosu, Acıbay yorumlar. $\mathrm{O}$, Almambet hakkında bilgi verdikten sonra şunları ifade eder:

\begin{tabular}{|c|c|}
\hline \multicolumn{2}{|c|}{ S. Orozbakov, VI. kitap: s. 376, 14827-14865. satırlar } \\
\hline Manas Destanı (Özgün Metin) & Türkiye Türkçesine Aktarımı \\
\hline Aybatı bar colborsuy, & Haşmetli kaplanın, \\
\hline Colbors bolso coldoşuy, & Kaplan ise yoldaşın \\
\hline Almambet kelip siz cakka, & Almambet gelip biz tarafa, \\
\hline Arkası tiyip biz cakka. & İyiliği dokunur bizlere. \\
\hline Ak tuygun bolgon kuşuyuz, & Beyaz kartal olan kuşunuz, \\
\hline Duşmanga tiygen muşunuz, & Düşmana vurulan yumruğunuz, \\
\hline Kanattular cigilıp, & Kuşların secde edip, \\
\hline Kaşııııga kelgeni & Önӥnӥze gelmesi \\
\hline Kak özüyö sıyınıp & Tam kendine tapınıp \\
\hline Siymıktuu erdin baarısı & Şerefli erlerin tamamı \\
\hline Siyınat eken özüyö, & Tebcil edecekmiş kendine, \\
\hline Kayıptın baarı sıyınıp & Gaiplerin hepsi taparak \\
\hline Körüngön eken közüyö, & Görünmüss senin gözüne, \\
\hline Alıskı cerde Kitaylar & Uzak yerdeki Çinliler \\
\hline Alınat eken özünö. & Bağlı olacakmış kendine. \\
\hline Böktör-böktör beliniz, & Stralı dağ belleriniz, \\
\hline Mömölüü cıgaç ceriniz, & Meyveli ağaç yeriniz, \\
\hline Tokson uruu Özübek, & Doksan boy Özbek, \\
\hline Tolkugan Kırgız eliniz, & Dalgalanan Kırgız halkınız, \\
\hline Toktolboy kelet eken go & Durmadan gelecekmiş \\
\hline Şol Almambet eriniz! & O Almambet eriniz! \\
\hline Bu düynödö coldoşun, & Bu dünyada yoldaşın, \\
\hline $\mathrm{O}$ düynödö koldoşun, & Öbür dünyada koldaşın, \\
\hline Kelet eken tüştögü & Gelecekmiş rüyadaki \\
\hline Almambet arstan coldoşun! & Almambet arslan arkadaşın! \\
\hline Kut bolot eken tagı1ız, & Kutlu olacakmış tahtınız, \\
\hline Açılgan eken da küçöp & Açılmıļ daha güç alıp, \\
\hline Alda bergen bagınız, & Allah veren bahtınız, \\
\hline Cangan eken şamınız! & Yanmış sizin meşaleniz! \\
\hline Ömür dooran sürüşüp, & Birlikte güzel hayat sürüp, \\
\hline Ekööndün közün ötkönçö & İkinizin ömrünüz geçince \\
\hline Sinbayt eken şagıııı! & Kırılmayacakmış dallarınız! \\
\hline Küldü duşman baarına & Bütün düşmanlara \\
\hline Kündöy tiyip tabıрız, & Dokunup güneş gibi tavınız, \\
\hline Küldögön eken bagııız, & Çiçeklenmiş bahçeniz, \\
\hline Külpöyüyön kün körüp, & Tam olarak gün görüp, \\
\hline Kükürttöyün küç alıp, & Kükürt gibi güç alıp, \\
\hline Külüp oynoyt ekenbiz & Gülüp güzel yaşayacakmışız \\
\hline Küldü oturgan baarıbız! & Burda oturan hepimiz! \\
\hline
\end{tabular}


Gördüğümüz gibi bu metinde Acıbay, Almambet'in Manas'a en yakın arkadaşı olacağını, onun sayesinde tahtının kutlu olacağını yani devletin güçleneceğini, düşmanların yenileceğini, bütün halka yararının dokunacağını belirtmektedir.

II. Köktürk Kağanlığı'nın kurucusu sayılan İlteriş Kağan'a da en büyük desteği Tunyukuk sağlamıştır. Bunu biz Tunyukuk Yazıtları'ndan öğrenebiliriz. ${ }^{1}$ Örneğin, "Kazgantukın üçün, udu özüm kazgantukın üçün

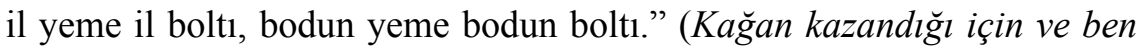
özüm kazandığım için devlet de devlet oldu, halk da halk oldu) (Tekin, 1994: 21-22) diye İlteriş Kagan ikisi birlikte çalıştıkları, hareket ettikleri için devletin devlet, halkın da halk olduğunu belirtmekte, "İlteriş Kagan kazganmsar, yok erti erser, ben, özüm Bilge Tunyukuk kazganmasar, ben yok ertim erser, Kapgan Kagan, Türk Sir bodun yerinte bod yeme, bodun yeme, kişi yeme idi yok erteçi erti. İlteriş Kagan, Bilge Tunyukuk kazgantuk üçün Kapgan Kagan Türk Sir bodun yorıdukı bu." [(İlteriş Kağan kazanmasa (idi), (ya da hiç) olmasa idi, ben kendim Bilge Tunyukuk kazanmasa (idim), (ya da) ben hiç olmasa idim Kapgan Kağan Türk Sir halkı ülkesinde boy da, halk da, insan da hiç olmayacak idi. İlteriş kağan ve Bilge Tunyukuk kazandığı için Kapgan Kağan'ın Türk Sir halkının gelişmesi (işte) budur)] (Tekin, 1994: 22-23) cümlesinde ise İlteriş Kağan ikisi çalıştıkları ve kazandıkları için Kapgan Kağan'ın ve Türk Sir devleti ile halkının geliştiğini ifade etmektedir. Hatta, Tunyukuk, yazıtında İlteriş Kağan ile Kapgan Kağan'ın kağan olmalarına bizzat kendisi vesile olduğunu vurgulamaktadır. Bir başka deyişle Tunyukuk, II. Köktürk Kağanlığı'nı kurulmasında İlteriş Kağan kadar emeği geçen, her zaman İlteriş Kağan'a yardım eden büyük bir devlet adamıdır.

S. Gömeç, Türk destanlarında geçen bazı vezirleri Tunyukuk'la ilişkilendirdiği makalesinde şunları ifade etmektedir:

'Üç kagana hizmet eden (İl-teriş, Kapgan, Bilge) Tunyukuk'un hatırası öldükten sonra da yaşamıştır. Uygur beglerinden Temür-Buka'nın, Çince Uygurların menşei ile ilgili yazııında onu ve soyunu saygıyla anmışlardır. Kendi aralarındaki çekişmeleri bir kenara bırakacak olursak, herşeye ragmen Tunyukuk, Türk milletinin yetiştirdigi en büyük ve en zeki devlet adamlarının başında gelir. İleri görüşlügü ve dehâsı sayesinde, zamanında Türk milleti en görkemli günlerini geçirmiştir. Bu yüzden biz Tunyukuk'un kolay kolay unutulmayacak bir kişi oldugunu düşünüyoruz. Dolayısıyla Türk milletinin hafizasında şu veya bu şekilde mutlaka yer etmiş olması gerekmektedir. Nasıl ki, meşhur Kapgan Kagan'ın oğlu Tonga Tigin, öldükten sonra unutulmayarak Tonga Alp Er ya da Alp Er Tonga

1 Tunyukuk Yazıtları hakkında geniş bilgi için bak.: Alyılmaz, C., Orhun Yazıtlarının Bugünkü Durumu. Ankara 2005, s. $177-250$. 
Manas Destanında Yer Alan Almambet ve Kül Çoro Ísimli Kahramanlar ile

Tarihte Yaşamış Tunyukuk ve Küli Çor Arasındaki Benzerlikler

olarak Kaşgarlı Mahmud'daki Afrasyab ile birleştirildiyse, Tunyukuk'un

da Türk destanlarında yaşadığını zannediyoruz (Gömeç, 2002: 442).

Gerçekten devlet yönetimindeki ve savaş seferlerindeki esas görevleri aynı olan Almambet ile Tunyukuk arasında birkaç benzerlik bulunmaktadır. Aşağıda bunlar üzerinde durulmuştur.

\section{A. Her ikisi Çin'de doğup büyümüşstür.}

Almambet S. Orozbakov ve Cusup Mamay varyantlarında bütün Çin'in asker kumandanı olan Soorondük'ün, S. Karalaev varyantında ise Çin hükümdarı Azizkan'ın çocuğudur. Yani soyu Çinlidir. O, Kazakların beyi Kökçö’dön İslamı öğrenince anne-babasından Müslüman olmalarını ister. Bunun üzerine babası onu öldürmek isteyince büyük bir savaş yaparak kurtulur. İlk önce Kökçö'nün yanında bulunan Almambet, daha sonra Manas'a katılır ve ömrünün sonuna kadar Manas'la birlikte olur.

Tunyukuk ise kendi yazıtında "Bilge Tunyukuk ben özüm Tabgaç iline kılıntım." [(Ben) Bilge Tunyukukum. Çin ülkesinde doğdum] (Alyılmaz, 2005: 184) diye Çin'de doğup büyüdügünü belirtmektedir. S. G. Klyaştornıy, F. Hirth'in araştırmalarına ve görüşlerine dayanarak Tunyukuk'u Çin kaynaklarında geçen ve Türklerin Aşide boyundan olan Yuançjen'le özdeşleştirmektedir. Babasının izinden giden Yuançjen, Çin ismini alarak Çin başkentinde iyi bir eğitim görmüştür. Çin yönetiminin güvenini kazanan Yuançjen, halkının çoğunu Türkler ve diğer bozkır boyları oluşturan Şanyuevo bölgesine önemli bir göreve getirilir. Onun görevi Çin hâkimiyeti altına alınan boyları tetkik etmekti. Çin İmparatoru Yuançjen'i İnşan'daki başkaldıran Türkleri bastırmak için gönderir. Ancak Yuançjen, başkaldıran Türkleri bastırmak yerine onların tarafına geçer ve İlteriş' in en yakın arkadaşı, danışmanı ve kumandanı olur. Türkçe Tunyukuk ismini alır (Klyaştornıy, 1964: 27-29). Bu bilgilere göre Almambet ile Tunyukuk'un her ikisi Çin'de doğup büyümektedirler. Ancak destandaki Almambet'in soyu Çinli ise, Tunyukuk Çinlileşmiş Türklerin soyundandır.

\section{B. Her ikisi iyi bir eğitim görmüştür.}

Tunyukuk Çin'de doğup büyüdüğü için Çin başkentinde iyi bir eğitim görmüştür. Çin müfettişi Se Den'in biyografisinde aralarında Tunyukuk'un da (Yuançjen) bulunduğu yabancı gençlerin Çin İmparatorunun sarayında Çin kanunlarını öğrendikleri, iyi bir eğitim aldıkları ve Çin'in sinır bölgelerine tayin edildiklerinde Çin'e zarar verdikleri anlatılmaktadır (Klyaştornıy, 1964: 27-28). Manas Destanı'ndaki Almambet de iyi bir eğitim almıştır: 


\begin{tabular}{|l|l|}
\hline \multicolumn{2}{|c|}{ S. Orozbakov, VI. kitap: s. 26, 435-441. satırlar } \\
\hline Manas Destanı (Özgün Metin) & Türkiye Türkçesine Aktarımı \\
\hline Caşı cetti segizge, & Yaşı ulaştı sekize, \\
Emi atası oylondu & Şimdi babası düşündü \\
Okuşka anı berişke, & Okumaya onu vermeyi, \\
Okuusun bildi Kıtaydın & Eğitimini aldı Çinlinin \\
Oyuna saldı berişte. & Düşüncesine yerleştirdi ferişte. \\
Altı cıl tamam okudu, & Altı sene boyu okudu, \\
Aribi köp Kıtaydın... & Harfi çok Çinlinin... \\
\hline \multicolumn{2}{|c|}{ S. Orozbakov, VI-VII. kitaplar: s. 37, 27980-27983. satırlar } \\
\hline Manas Destanı (Özgün Metin) & Türkiye Türkçesine Aktarımı \\
\hline Bilimi artık Almambet & Bilgisi fazla Almambet \\
Macusunu köp okup & Büyü, sihir çok okuyup, \\
İlimi artık Almambet & İlmi fazla Almambet \\
Mintip colgo salganı. & Öylece yola salmıştır. \\
\hline
\end{tabular}

İlk metinde Almambet'in babasının girişimi ile okula gidip altı sene okuduğu, Çin eğitimini aldığı ve harfi çok olan Çin yazısını öğrendiği anlatılmaktadır. İkinci metinde ise Rus seferi sırasında düşman sihircilerinin oluşturduğu değişik engellerin Almambet tarafından büyü, sihir sayesinde aşıldığı belirtildikten sonra, Almambet' in çok bilgili birisi olduğu ve büyü, sihiri çok okuduğu ifade edilmektedir. Yukarıda verilen bilgiler bu iki şahısın arasındaki en önemli benzerliği, eğitimli olduklarını göstermektedir.

\section{Her ikisi üstün savaş zekâsına sahip kumandanlardır.}

Bilindiği gibi Manas Destanı'nda ve Köl Tigin, Bilge Kagan ve Tunyukuk Yazıtları'nda anlatılan olayların büyük bir kısmı savaş seferleri ile ilgilidir. Tunyukuk, kendi yazıtında bu savaşların birçoğunun kendi teklifi ile gerçekleştiğini belirtmektdir. Örneğin, Çin'e yapılan savaş seferi hakkında şunları ifade etmektedir: "Türk bodun kılıngalı, Türk kagan olurgalı Şantun balıkka, Taluy ögüzge tegmiş yok ermiş. Kaganıma ötünüp sü eltdim. Şantun balıkka, Taluy ögüzke tegürtim." [Türk halkı yaratıla-

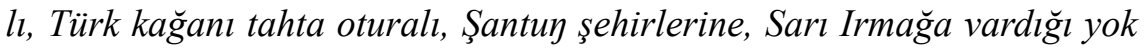
imiş. Kağanıma arz edip ordu sevk ettim. (Kağanımı) Şantuy şehirlerine, Sarı Irmağa kadar götürdüm] (Tekin, 1994: 8-9). Gördüğümüz gibi bu metinde Tunyukuk, ondan önce Türklerin hiç Çin'e sefer etmediklerini, bizzat kendisi kağana teklif ederek sefere çıktıklarını ve Çin'e ulaştıklarını dile getirmektedir. S. Gömeç, Tunyukuk'un üstün bir savaş zekâsına sahip olduğunu belirterek bunun kanıtı olarak onun önderliğindeki ordunun Kırgızlara yaptığı seferi göstermektedir (Gömeç, 2003a:). Çünkü bu sefer öncesinde Tunyukuk, aralarında Aşina hanedanlığına karşı ittifak kuran Çin, Kırgız ve On Ok kağanlarını birleştirmeden birer birer bertaraf etmek 
gibi bir stratejik plan kurmuştur. İlk önce Kırgızlara sefer etmenin doğru olacağını düşünmüştür. Sefer sırasında ise aşılması zor yoldan yürüyerek zaman kazanmış, geçilmesi zor geçidi geçmeyi başarmış ve Kırgızları aniden bastırarak Kırgız Kağanı Bars Beg'i öldürmüş̧ür:

“İlk Kırkızka süleser yeg ermiş tedim. Kögmen yolı bir ermiş, tumış teyin eşdip bu yolın yorısar yaramaçı tedim. Yerçi tiledim. Çölgi Az eri bultum. Eşitdim Az yir yolı Anı birle ermiş. Bir at orukı ermiş, anın barmış, ayar aytıp bir atlıg barmış teyin, ol yolun yorısar unç tedim. Sakıntım. Kaganıma ötüntüm. Sü yorıtdım. Atlat tedim. Ak Termel keçe ugur kaltdım. At üze bintüre karıg sökdüm. Yokaru et yete yadagın ıgaç tutunu agturtum. Öyreki er yugurça 1dıp 1 bar baş aşdımız. Yubulu intimiz. On tünke yantakı tug ebirü bardımız. Yerçi yer yanılıp boguzlantı. Buyadıp, kagan yelü kör temiş. Anı subka bardımız, ol sub kodı bardımız. Asıngalı tüşürtimiz. Atıg 1ka bayur ertimiz. Kün yeme, tün yeme yelü bardımız. Kırkızıg uka basdımız. Usın sünügin açdımız. Kanı, süsi terilmiş, süyüşdümüz, sançdımız. Kanın ölürtümüz. [Önce Kırgızlara sefer etsek iyi olur dedim. Kögmen yolı bir imiş, (o da) kapanmiş diye işitip 'Bu yoldan yürüsek iyi olmayacak' dedim. Kllavuz istedim. Bozkırdaki Azlardan bir adam buldum. (Ondan şöyle) işittim: Az ülkesi yolu Anı ırmağı boyunca imiş. Ancak bir atın geçebileceği kadar imiş. (Kendisi) o yoldan bir kez gitmiş. Ona sorup 'Bir atl gitmiş olduğuna göre o yoldan yürüyebiliriz' dedim. Düşündüm. Kaganıma arz ettim. Orduyu yürüttüm. (Beylere) 'Askerleri atlara bindirin!' dedim. Ak Termel (ırmağını böylece) geçerek zaman kazandım. (Askerleri) at üzerine bindirip karları söktüm. Yukartya doğru, atları yedeğe alarak, ağaçlara tutuna tutuna (askerleri) dağa ağdırdım. Öncü askerleri (karları) yoğuruncasına yürütüp ormanla kaplı doruğu aştık. (Ondan sonra) yuvarlanarak indik. On gecede yandaki engeli dolanarak gittik. Kılavuz yanıld ve boğazlandı. Sikılıp kağan 'Sürün atları!' demiş, Anı ırmağına vardık... O ırmak boyunca yol aldık. Tırmanmak için (askerleri atlardan) indiriyorduk. Atları ă̆açlara bağglyyorduk. Gece gündüz dört nala gittik. Kırgızları uykuda iken bastık. Uykularını mızraklarımızla açtık. (Bu arada) hanları ve orduları toparlanmış. Savaştık, mızrakladık. Hanlarını öldürdük.] (Tekin, 1994: 10-13).

Tunyukuk'un Manas Destanı'ndaki izi olabileceğini düşündüğümüz Almambet de aynı özelliğe, üstün savaş zekâsına, kumandanlık yeteneğine sahiptir. O, tıpkı Tunyukuk gibi Manas'a sefere çıkmak önerilerinde bulunmaktadır: 


\begin{tabular}{|l|l|}
\hline \multicolumn{2}{|c|}{ S. Orozbakov, VI-VII. kitaplar: s. 6-7, 25597-25610. satırlar } \\
\hline Manas Destanı (Özgün Metin) & \multicolumn{1}{|c|}{ Türkiye Türkçesine Aktarımı } \\
\hline Ayagı Aral köl, Oroldu, & Sonu Aral göl, Ural'ı \\
Alıp turgan olordu, & Amış olan onları, \\
Almambet baatır oylop cür & Almambet kahraman düşünmektedir \\
Oruska kazat bolordu. & Ruslara sefer etmeyi. \\
Kün batıştan Kıybanı, & Gün batıdan Kıyba'yı, \\
Kürkürögön Kırgızdar & Haykıran Kırgızlar \\
Kübüp ışın kıylanı, & Birçok halkı zapt edip, \\
Alıp kelip kızdarın, & Getirip kızlarını, \\
Baarı kıştap, caz çıgıp, & Klşı geçirip, bahar gelip, \\
Bargananın kıştagın. & Fergana'nın köyünde. \\
Ataktuular Alayda, & Ünlüler Alay'da, \\
Attanıp kazat kılam dep, & Atlanıp sefere çıkacağız diye, \\
Arstan Manas, Almambet & Arslan Manas, Almambet \\
Ayttı kabar dalayga. & Haber gönderdiler birçoğuna. \\
\hline
\end{tabular}

$\mathrm{Bu}$ metinde Almambet'in Ruslara sefer yapmayı düşündüğ̈̈, onun önerisiyle Manas ile ikisinin halka haber vererek sefere hazırlanmaya başladıkları anlatılmaktadır. Bunun gibi Almambet'in önerisi ile Kencut ülkesindeki Aygan Kan'a da sefer ederler. Gördügümüz gibi Almambet, Tunyukuk gibi hükümdarına savaş seferlerini önermekte, böylece devletin güçlenmesinde büyük katkı sağlamaktadır.

Tunyukuk ile Almambet sadece sefer düzenlemelerini yapmakla yetinmemekte, sefere çıkan orduya kumandanlık yaparak sefer sırasında karşılaşılan engelleri aşmakta, saldırıları planlamakta da önemli rol oynamaktadirlar.

Almambet ile Tunyukuk'un her ikisi savaş seferlerinde orduyu yönetmekte, başkumandanlık yapmaktadırlar. Örneğin, On Oklara yapılan seferde İlteriş Kağan, eşi vefat edince orduyu yönetme görevini Tunyukuk'a vermektedir: "Bilge Tunyukuka, baya aydı: 'Bu süg elet' tidi. 'Kıyınıg köylünçe ay, ben saya ne ayayın' tidi. [Bilge Tunyukuk'a, bana dedi (ki): 'Bu orduyu sevk et' dedi, '(suç işleyenlerin) cezalarını dilediğin gibi ver. Ben sana (daha) ne diyeyim?'dedi] (Tekin, 1994: 14-15). İlteriş Kağan, bu mesajında Tunyukuk'a orduyu yönetme görevini vererek onun yeteneğine inandığını göstermekte, bundan dolayı vermek istediği ögüdünün olmadığını ifade etmektedir.

Almamabet'e ise destanda anlatılan en büyük savaş sırasında, Çin'e yapılan Çoך Kazat (Büyük Gazavat) seferinde orduyu yönetme görevi, han unvanı verilmiştir. İlk önce bu görev Bakay'a verilmişti. Daha sonra Manas, Almambet'in orduyu yönetme yeteneğini, Çin'i iyi bilmesini dikkate alarak bu göreve Almambeti önerir: 
Manas Destanında Yer Alan Almambet ve Kül Çoro Ísimli Kahramanlar ile Tarihte Yașamıș Tunyukuk ve Küli Çor Arasındaki Benzerlikler

\begin{tabular}{|l|l|}
\hline \multicolumn{2}{|c|}{ S. Orozbakov, VIII. kitap, s. 249, 17646-17652. satırlar } \\
\hline Manas Destanı (Özgün Metin) & Türkiye Türkçesine Aktarımı \\
\hline Kankor Manas kep aytat & Kankor Manas söylüyor: \\
'Ay, kalayık dep aytat, & 'Hey, halayık diyor, \\
Baarınarga ep bolso, & Hepinize uygun gelirse, \\
Babayar aytar kep bolso, & Ecdatlarınızın söylediği söz ise, \\
Aytkanın makul körölük, & Dediklerini makul görelim, \\
Uşu coldun biyligin & Bu seferin yöneticiliğini \\
Almambetke berelik' & Almambet'e verelim' \\
\hline
\end{tabular}

Toplanmış olan beyler, asker kumandanları, Manas'ın teklifini uygun görürler. Böylece orduyu yönetme görevi, han unvanı Almambet'e verilir. Almambet'in orduyu yöneten han olduğunu kırk çoronun birisi olan Iramandın Irçı Uulu duyurur:

\begin{tabular}{|l|l|}
\hline \multicolumn{2}{|c|}{ S. Orozbakov, VIII. kitap, s. 283, 20200-20206. satırlar } \\
\hline Manas Destanı (Özgün Metin) & Türkiye Türkçesine Aktarımı \\
\hline Bakaydan kandık ketti dep, & Bakay'dan hanlık gitti diye, \\
Badışalık ökümöt & Padişahlık hükûmet \\
Almambetke öttü dep, & Almambet'e geçti diye, \\
Ajdayar uşu kepti dep, & Anlayın bu sözü diye, \\
Carlıgı calgan degendi & Emri yalan diyeni, \\
Tübünö kazbay cetti dep, & Sonuna kadar cezalandır diye, \\
Tüşüngün uşu kepti dep. & Anlayın bu sözü diye. \\
\hline
\end{tabular}

Gördüğ̈̈müz gibi, hem Tunyukuk hem de Almambet önemli savaş seferlerinde orduyu yönetmektedirler. Yani her ikisi başkumandan görevini yapmışlardır.

\section{Ç. Her ikisi Türkleri cezalandırmak için yola çıkarak Türklerin safına geçmiştir.}

Çin yönetiminin güvenini kazanan Yuançjen (Tunyukuk), halkının çoğunu Türkler ve diğer bozkır boyları oluşturan Şanyuevo bölgesine önemli bir göreve getirilir. Onun görevi Çin hâkimiyeti altına alınan boyları tetkik etmekti. Çin İmparatoru, Yuançjen'i İnşan'da başkaldıran Türkleri bastırmak için gönderir. Ancak Yuançjen, başkaldıran Türkleri bastırmak yerine onların tarafına geçer ve İlteriş'in en yakın arkadaşı, danışmanı ve kumandanı olur. Türkçe Tunyukuk ismini alır (Klyaştornıy, 1964: 27-29; Klyaştorniy, 1966: 205-205).

Manas Destanı'ndaki Almambet de Çin'in bir bölgesine saldıran Türkleri cezalandırmak için yola çıkar: 


\begin{tabular}{|c|c|}
\hline \multicolumn{2}{|c|}{ S. Orozbakov, VI. kitap, s. 26, 435-441. satırlar } \\
\hline Manas Destanı (Özgün Metin) & Türkiye Türkçesine Aktarımı \\
\hline $\begin{array}{l}\text { Ugup alıp Almambet: } \\
\text { 'Uşu emne korduk dep, } \\
\text { Atpay kakan köp curtu } \\
\text { Alakanday çantuuga } \\
\text { Arzan kanday bolduk? dep, } \\
\text { Ketip mından barbasam, } \\
\text { Kentunga kabar salbasam, } \\
\text { Tūşaa kalaa köp curtun } \\
\text { Tutaş cıyıp albasam, } \\
\text { Altaydagı Türükkö } \\
\text { Abıdan salıp tülükkö, } \\
\text { Eskimustun kün cagı, } \\
\text { Tenir-Noor tün cagı, } \\
\text { Amur menen Subayıs } \\
\text { Anda bolgon çantuuga } \\
\text { Akır zaman salbasam } \\
\text { Almambet bolboy kuruyun. }\end{array}$ & 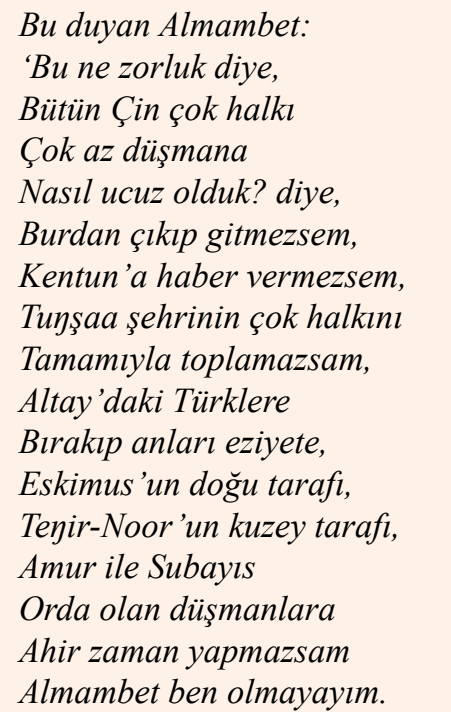 \\
\hline
\end{tabular}

Gördüğümüz gibi bu metinde Almambet, 'Çin'in bir bölgesine saldıran Altay'daki Türklere sefer düzenleyip, intikam almazsam Almambet olmayayım' diye sinirlenmektedir. O, Altay'daki Türklere yaptı̆̆ 1 sefer sırasında Kazakların kahramanı Kökçö ile görüşür. Ondan İslamı öğrenip daha sonra Türklerin safına geçer. Demek ki tarihteki Tunyukuk ile destandaki Almambet'in Türklere geçmesi de benzer motife sahiptir.

Almambet ile Tunyukuk arasından bu benzerliklerden hareketle destandaki Almambet'in Türk tarihinde çok büyük bir önemi olan Tunyukuk'un izi olabileceğini ileri sürmek mümkündür. Hiç değilse Almambet'in kişiliği, imajı oluşturulurken tarihte yaşayan Tunyukuk'un bazı özelliklerinin dikkate alındığ 1 kesindir. Bilindiği gibi Almambet'in tarihteki prototipi hakkında değişik görüşler ileri sürülmüştür. Örneğin, Almambet'in kişiliğini, imajını ayrı bir monografide ele alan halk bilimci R. Sarıpbekov ile tarihçi A. N. Bernştam, Almambet'in tarihteki prototipi, onun kişiliğini, imajını oluşturmada esas olan tarihî şahıs olarak 840 yılında Kırgı-Uygur Savaşı esnasında Kırgızların tarafa geçen Uygur kumandanı Külüg Baga'y1 görmektedirler (Bernştam, 1968: 168; Sarıpbekov, 1977: 138-140). Ancak daha sonra Manas Destanı'nın 840 yılındaki Kırgız-Uygur Savaşı'ndan dolayı ortaya çıktığı tezi S. G. Klyaştornıy, R. Kıdırbaeva vd. gibi bilim adamları tarafından çürütüldüğü için bu görüşü kabul etmek mümkün değildir. 
Manas Destanında Yer Alan Almambet ve Kül Çoro Ísimli Kahramanlar ile

Tarihte Yaşamış Tunyukuk ve Küli Çor Arasındaki Benzerlikler

\section{Kül Çoro ve Küli Çor}

İlk bölümde II. Köktürk Kağanlığı'nın kuruluşunda çok büyük rol oynayan büyük devlet adamı Tunyukuk'a benzetilen Almambet'in oğlu Kül Çoro adını taşımaktadır. A. Caynakova ile A. Boronov, Kül Çoro kişi adının Kırgız Türkçesi verileriyle açıklanamadığını ve eski Türkçe bir kişi adı olduğunda şüphe olmadığını belirtmektedirler. Onlar bu kişi adının eski Türkçedeki ünlü, saygın anlamına gelen külig kelimesi ile çor kelimesinden oluşan Külig Çor isminin Küli Çor>Kül Çoro şeklinde değişmesinden ortaya çıktığını düşünmektedirler (Caynakova ve Boronov, 1995: 578579). Gerçekten de Köktürk harfli yazıtlardan İhe-Huşotu Yazıtı, Küli Çor adlı ünlü Türk devlet adamının, kumandanının anısına dikilmiştir (Malov, 1959: 25; Gömeç, 2000: 66; Aydın, 2012: 251-272). Söz konusu yazıttan anlaşıldığına göre Küli Çor, Köktürk devletinin yeniden kurulmasında, düşmanların bertaraf edilmesinde çok büyük emeği geçen bir devlet, asker adamı olup seksen yaşında vefat etmiştir. Bu kişinin adı Bilge Kağan yazıtında Kül Çor $(4>\lambda Y N$ F), Hoytu Tamir I yazıtında Küli Çor ( $4>-$ ג「YN₹) şeklinde geçmektedir: Kanım Türk Bilge Kagan olurtukınta Türk amtı begler, kisre Tarduş begler, Kül Çor başlayu ..... (Babam Türk Bilge Kağan tahta oturduğunda şimdiki Türk beyleri, batıdaki tarduş beyleri, Kül Çor başta olmak üzere....) (Bilge Kağan, Güney 13); İn Öz İnançu, Y1lan Öz İnançu, Tarduş Küli Çor Beş Balıkka barır biz ((Biz) İn Öz İnançu, Yılan Öz İnançu, Tarduş Küli Çor Beş Balık'a gidiyoruz) (Hoytu Tamir I) (Malov, 1959: 47; Tekin, 2008: 68-69). Gördüğümüz gibi Manas Destanı'ndaki Kül Çoro ile yazıtlardaki Küli Çor kişi adları aynı isimdir. Hatta Eski Türkçe Küli Çor kişi adı Manas Destanı'nda Almambet'in oğlunun ismi olarak korunmuş diyebiliriz. Zaten A. Guluev, Manas Destanı'ndaki kişi adlarını ele alan bildirisinde destanındaki Kül Çoro'yu yazıtlardaki Küli Çor olarak kabul etmektedir (Guluyev, 1995: 124). Bu kişi adlarının benzerliği rastgele bir benzerlik mi? Ya da yazttlarda hayatı anlatılan Eski Türk kahramanı Küli Çor ile Manas Destanı'ndaki Kül Çoro'nun arasında herhangi bir tarihî ilişki var mı? Bunu tespit etmek için tarihi şahıs olan Küli Çor ile destan kahramanı Kül Çoro'yu karşılaştırarak benzerliklerini araştırmak gerekmektedir. Aşağıda birer birer değineceğimiz gibi Manas Destanı'ndaki Kül Çoro ile İhe Huşotu yazıtındaki Küli Çor arasında isimlerinden başka da birkaç önemli benzerlik bulunmaktadır.

\section{A. Her ikisi birçok savaşa katılan kahramandır.}

Manas ölünce onun akrabalarından zulm gören eşi Kanıkey, oğlu Semetey'i alıp, memleketine, Buhara'ya gider. Semetey büyüyünce de vatanına, Talas'a dönmek ister. Bunu uygun gören Kanıkey, Semetey'e birçok bilgi verir. Bu bilgiler içerisinde Almambet'in oğlu Kül Çoro da anlatıl- 
maktadir:

\begin{tabular}{|l|l|}
\hline \multicolumn{2}{|c|}{ S.Karalaev, Semetey, s. 267, 22073-22077. satırlar } \\
\hline $\begin{array}{l}\text { Manas Destanı. Semetey } \\
\text { (Özgün Metin) }\end{array}$ & Türkiye Türkçesine Aktarımı \\
\hline Oşol turgan Kül Çoro & O duran Kül Çoro \\
Coldoş bolso özünö & Arkadaş olursa kendine \\
Şay koldogon şer bolot, & Şahımerdan 'ın kolladığı kahrman olur, \\
Özüydön öödö er bolot, & Kendinden üstün er olur, \\
Mingeni tulpar sur bolot, & Bindiği yürük sur at olur, \\
Özüyö coldoş çın bolot. & Kendine gerçek dost olur. \\
Dobul kelse cel tiybeyt, & Firtına olursa hava değmez, \\
Kıykırgan coogo mal berbeyt. & Haykıran düşmana hayvan vermez. \\
Cetik belin kurçanat & Belini sağlam bağlar \\
Ceti san kaptap kol çıksa & Çok fazla düşman gelirse \\
Celbegey kirip kol salat. & Zirh giymeden saldırır. \\
Bel baylagan bel oşol & Güveneceğin kahraman odur \\
Ayaş atan Almambet & Babanın dostu Almambet'in, \\
Artıkça bergen arnap & Özel olarak verdiği \\
Belekke kalgan şer oşol. & Armă̆an kalan kaplan odur. \\
Sen özüydön kulunum, & Senin kendinden yavrum, \\
Nayza boyu bir kulaç & Mızrak boyu üstün olan \\
Arta tiyçü şer oşol. & Cesur kahraman kaplandır. \\
Kayran canı̄ ölgüçö, & Sicak canın ölünceye kadar, \\
A düynö cüzün körgüçö & O dünyaya göçünce \\
Adal kızmat bir kılıp, & Hilesiz hizmet edip sana, \\
Özüyö coldoş bolçu şer oşol. & Kendine arka olacak kaplandır. \\
Caynagan kızıl çok bolot & Kaynayan kızll ateş olur \\
Bet alsa san kol toktolot. & Saldırdığında sayısız düşman durur. \\
\hline
\end{tabular}

Gördüğümüz gibi bu metinde Kanıkey, Kül Çoro'nun çok cesur bir kahraman, Semetey'in yanında sadık bir dost olacağını ifade etmektedir.

İhe Huşotu Yazıtı'nda hayatı anlatılan Küli Çor da tıpkı Kül Çoro gibi cesur bir kahramandır. Yazıtta Beşbalık'a dört kez sefer ettiğini, Karluklarla ve Taciklerle savaştığını, Uygurlara yedi kere sefer düzenlediğini anlatmaktadır. Bu savaşlarda kendisi bizzat karşılaşlara saldırarak büyük kahramanlıklar yapmaktadır. Örneğin, Karluklarla olan savaşta İdil adlı birisinin ak atına binip boğa gibi hücüm etmektedir: '(Bil)ge Küli Çor anta kisre Karlukka yeme sünüş(dük)de İdil akin binip, oplayu tegip, sança 1dıp, topulu ünti (Bilge Küli Çor, ondan sonra Karluklarla yeniden savaştığında İdil'in ak atına binip boğa gibi saldırıp, mızraklayıp (düşman saflarını) delip çıktı)' (İhe Huşotu, 19) (Malov, 1959: 28-29; Tekin, 2003: 226; Mert, 2015: 71). 
Manas Destanında Yer Alan Almambet ve Kül Çoro Ísimli Kahramanlar ile

Tarihte Yașamıș Tunyukuk ve Küli Çor Arasındaki Benzerlikler

Kül Çoro, Semetey'e, daha sonra Semetey'in oğlu Seytek'e nasıl danışmanlık yapıp askere kumandanlık etmişse Küli Çor da Bilge Kağan'ın danışmanlığını ve kumandanlığını yapmıştır. Örneğin, Kıtany ve Tatabılarla olan savaşlara hem danışmanı ve bilgesi, hem de başkomutanı ve kahraman savaşçısı olarak katılmıştır: 'Kıtany, Tata(b1... tapa sü)ledükde, beş sünüş sünüşdükde, Küli Çor ança bilgesi, çabış1 erti. Alp1, bökesi erti (Kitan ve Tata(bılara doğru sefer et)tiklerinde, beş kere savaştıklarında Küli Çor danışmanı, başkomutanı idi. Kahramanı ve güçlü savaşçısı idi)' (İhe Huşotu, 17) (Malov, 1959: 27-29; Tekin, 2003: 226; Mert, 2015: 71, 77).

\section{B. Her ikisi kağan oğullarına atabeylik yapmıştır.}

Yazıtlardaki Küli Çor ile Manas Destanı'ndaki Kül Çoro'nun arasındaki en önemli benzerlik onların devlet düzeyindeki görevleri ile kağanlarla, hükümdarlarla olan ilişkileri bakımından olan benzerliktir.

S. Gömeç, Köl İç Çor'luk/Küli Çorluk makamının Türklerde eski bir kurum olan ve hükümdar çocukları olan şadların akıl hocalarını bildiren "atabeylik" görevini yansıttığını düşünmektedir (Gömeç, 2003b: 35). Bu bağlamda T. A. Guriev'in 'Bir isim destanlara öylesine girmez. Bu isimlerin her biri herhangi bir tarihî-kültürel veriyi, olguyu yansıtmaktadır' demesi çok önemlidir (Guriev, 1983: 107). Buna göre Eski Türklerdeki Küli Çorluk makamı ile destandaki Kül Çoro'nun arasında bir ilişki olmalıdır. Gerçekten de Manas Destanı'ndaki Kül Çoro, Manas'ın oğlu Semetey'e arkadaşl1k edip, onunla birlikte Çinlilerle, iç düşmanlarla savaşan bir kahraman ise, Semetey'in oğlu Seytek'e, yani hükümdar çocuğuna danışmanlık yapan, her türlü konuda yardımcı olan, bir başka deyişle Seytek'e atabeylik yapan şahıstır (Caynakova ve Boronov, 1995: 578-579). Örneğin, Semetey'in eşi Ayçürök, Kül Çoro'yu bulduğunda onun başına önceden hazırladığı miğferi giydirerek oğlu Seytek'e destek olmasını, onu eğitmesini ister:

\begin{tabular}{|l|l|}
\hline \multicolumn{2}{|c|}{ S.Karalaev, Seytek, 1960: 80} \\
\hline $\begin{array}{l}\text { Manas Destanı. Seytek } \\
\text { (Özgün Metin) }\end{array}$ & Türkiye Türkçesine Aktarımı \\
\hline Cobolonduu inindi & Tecrübesiz kardeşini \\
Coldoş kılıp alıyız, \\
Coogo dümök salıyız! & Kendinize arkadaş edininiz, \\
\hline
\end{tabular}

Bunu söyleyen Ayçürök, Seytek'i Kül Çoro'ya getirir. Seytek'i gören Kül Çoro başından geçenleri, Manas, Semetey hakkında bilgileri anlatır. Seytekle ikisi düşmanları bertaraf edeceklerini söyler. Bunun üzerine Seytek, şunu der: 


\begin{tabular}{|l|l|}
\hline \multicolumn{2}{|c|}{ S.Karalaev, Seytek, 1960: 86} \\
\hline $\begin{array}{l}\text { Manas Destanı. Seytek } \\
\text { (Özgün Metin) }\end{array}$ & Türkiye Türkçesine Aktarımı \\
\hline Uktum şeker sözüydü, & Dinledim tatlı sözlerini, \\
Şer Kül Çoro abakem, & Kaplan Kül Çoro amcam, \\
Bügün kördüm közündü, & Bugün gördüm gözünü, \\
Armanım cok kudayga, & Ukdem kalmadı Yaradan'a, \\
Ata kılam özündü, & Baba edineceğim seni, \\
Bilbegendi bilgizgin. & Bilmediğimi öğretin. \\
\hline
\end{tabular}

Gördüğümüz gibi Seytek, Kül Çoro’yu gördüğünde sevinmekte, kendisini baba yerine tutacağını belirterek bilmediklerini öğretmesini, eğitmesini istemektedir. Bunun üzerine Kül Çoro, her zaman Seytek'in yanında olup ona danışmanlık yapmakta, gerektiğinde orduyu yöneterek savaşları kazanmasında, düşmanlarını bertaraf etmesinde çok büyük rol oynamaktadır, yani atabeylik yapmaktadır. Bu bakımdan yazıtlardaki Küli Çor'a benzemektedir. $\mathrm{Bu}$ benzerliği tarihte, Eski Türklerde olan bir kurumun, atabeylik kurumunun destanlardaki izi olarak açıklamak da mümkündür. T. N. Kondratyeva, Rus destanlarındaki kişi adlarını ele alan eserinde, destanlarda kişi adı olarak kullanılan cins isimlerin hiç bir zaman kendi anlamlarını yitirmediğini belirtmekte ve bunu destanlardaki kişi adlarının herhangi bir tarihî-kültürel olguyu, veriyi yansıtan araç olmasıyla açıklamaktadır (Kondratyeva, 1967: 252). Dolayısıyla Manas Destanı'ndaki Kül Çoro’nun kişiliğindeki hükümdar oğluna atabeylik yapma motifini Eski Türklerdeki Küli Çorluk makamıyla açıklamak mümkündür.

\section{Küli Çor Tunyukuk'un akrabası, Kül Çoro Almambet'in oğlu.}

Destandaki Kül Çoro, Çinli bir kahraman olup, daha sonra İslamiyeti kabul eden, Manas'ın en yakın arkadaşı olan Almambet' in oğludur. S. Gömeç, Köl İç Çor'un/Küli Çor'un tarafımızdan Almambet'e benzetilen Tunyukuk'un yakın bir akrabası olduğunu düşünmekte ve şunları ifade etmektedir: 'Nasıl Tunyukuk, İlteriş’in çabışlığını yaptıysa, Işbara Bilge Köl İç Çor da Bilge Kağan'ın çabışı olmuştur ki, yazıtında bu dile getirilmektedir' (Gömeç, 2003b: 35). Biz, yukarıda İlteriş Kağan'ın çabışlığını yapan Tunyukuk'u Manas'ın çabışlığını yapan Almambet'e benzetmiştik. Kül Çoro tarafımızdan Tunyukuk'a benzetilen Almambet'in oğludur. Kül Çoro'yu kendisine benzettiğimiz Küli Çor ise S. Gömeç'e göre Tunyukuk'un yakın akrabasıdır. İşte bu durum da destandaki Kül Çoro ile yazıttaki Küli Çor arasında ilişki aramamıza olanak sağlamaktadır. 
Manas Destanında Yer Alan Almambet ve Kül Çoro İsimli Kahramanlar ile

Tarihte Yașamıș Tunyukuk ve Küli Çor Arasındaki Benzerlikler

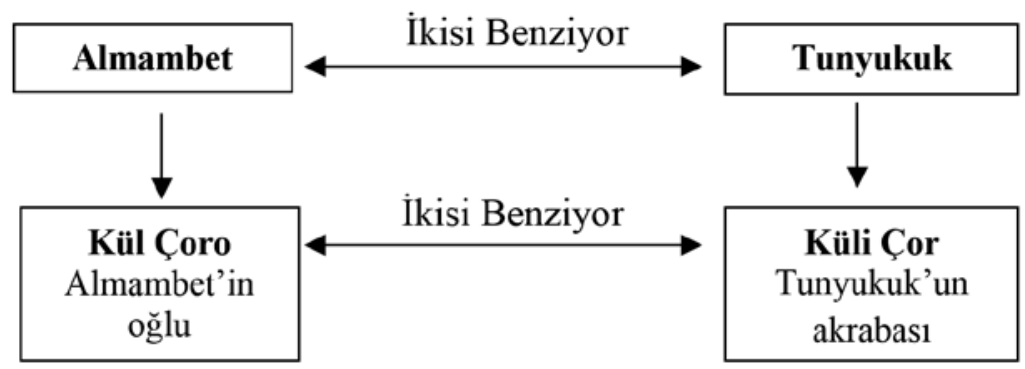

V. A. Jirmunskiy, folkloristikteki tarihî okul, destan kahramanlarına her zaman prototip bulmakla meşgul diye tenkit etmektedir (Jirmunskiy, 1995: 103). Elbette, destanlardaki kahramanların hepsinin tarihte prototipi olmuştur demek çok yanlıştır. Ancak destanın esasını oluşturan önemli kahramanların kişiliğinde, imajında tarihî şahısların etkisinin bulunması da inkar edilemez bir gerçektir. Hiç değilse destan kahramanlarının imajı oluşturulurken o kahramanın özelliğine göre tarihte yaşayan önemli şahıslar dikkate alınmıştır. Bilindiği gibi Manas Destanı, destanı söyleyen manasçılar için de, dinleyen halk için de - tamamı gerçek olmasa da - Kırgız halkının tarihini yansıtan bir destan olarak kabul edilmiştir. Çünkü Manas Destanı Altay, Saha destanları gibi mitolojik devri değil, orta asırları tasvir eden bir destandir (Reichl, 2014: 47-53). Manas Destan1, temelini tarih oluşturan kahramanlık destanıdır (Bernştam, 1968: 176). Kahramanlık destanlarının asıl amacı ise halkın tarihî geçmişini yansıtmaktır (Tolstova, 1983: 10). Dolayısıyla Manas Destanı'nı icra eden manasçılar da dinleyen halk da destanı her zaman redakte, revize ediyordu. Bu konuda S. Musaev, aşağıdakileri ifade etmektedir: 'Üstelik gelenek olarak, manasçıların söylediği metinlerin dikkati çeken kısımları 'halk redaksiyonundan' geçmiş, dinleyiciler tarafından tartışılmıştır. Öyle tartışmalarda destanı söyleyenler sorulara güvenilir, doyurucu cevap bulamazsa, söylediklerini dineyicilere anlatıp kanıtlayamazsa halk önünde saygınlığını kaybetme tehdidi vardı' (Musaev, 2002: 35).

Dolayısıyla manasçılar söylediği bilgileri, olayları tarihî gerçekle temellendirmeye, tarihî şahıslarla kanıtlamaya, önemli olayları, kahramanlar1 kendilerinden önceki ünlü manasçılardan öğrenmeye çalışmışlardır. Örneğin, S. Orozbakov, Almambet hakkındaki bilgileri, metni Ş. Rısmendeev aracılığıyla efsanevi büyük manasçı Balık'tan öğrenmiştir (Sarıpbekov, 2002: 165). Balık ise XIX. asırda yaşayan, sanat faaliyetleri bu asrın başına ve ortasına denk gelen büyük manasçıdır. Dolayısıyla onun Almambet hakkında söyledikleri, demek ki S. Orozbakov aracılığıyla günümüze ulaşan Almambet hakkındaki bilgiler kitaplardan edinilmiş bilgiler değildir. 
Bundan dolayı Manas Destanı'ndaki Almambet ile yazitlardaki Tunyukuk ortasındaki benzerlikler için halkın tarihî hafızasında korunan, Manas Destanı'nda yaşayan tarihî olaylarla ilişkili tarihî benzerlikler demek mümkündür. Özellikle Küli Çor ile Kül Çoro arasında dikkat çekici, inkâr edilmesi zor benzerliklerin bulunması, Manas Destanı'ndaki bazı tarihî olayların, etnografik ve kültürel olguların, kahramanların temelinde Eski Türk devrine ait tarihî olayların, tarihî şahısların bulunduğunu göstermektedir.

\section{Sonuç}

Manas Destanı'ndaki Almambet, Kül Çoro gibi kahramanlarla Eski Türk tarihindeki Tunyukuk, Küli Çor gibi önemli şahısların ortasında büyük benzerliklerin bulunması Manas Destanı'nın VII-XI. asırlar arasındaki eski Türk devrini yansitan bir destan olduğunu göstermektedir. Bu bağlamda 'Neden Manas Destanı'nda eski Türk tarihi ve kültürü korunmuş olabilir?' şeklindeki bir soru oluşur. V. Ya. Propp, folklor eserlerinin tarihî yönden araştırılmasında destanlar için en önemli hususun olay örgüsü olduğunu, destanların olay örgüsünün her zaman belirli bir amacı, bir ideali yansittığını, ideal fikirlerin ise belirli bir zamanda ve belirli bir yerde ortaya çıktığını belirttikten sonra destanların tarihî yönden araştırılmasının asıl amacının işte bu eserlerde yansitılan ideal fikrin hangi dönemde ortaya çıktığını tespit etmek olduğunu ifade etmektedir (Propp, 1998: 201). Manas Destanı'nın S. Orozbakov varyantının olay örgüsüne bakarsak, destan Manas'ın dedesi Nogoy'un dört oğlunun Çinliler tarafından dört ayrı yere sürülmesini, Manas'ın babası Cakıp'ın, Kırgızların bir bölümünün Altay'daki hayatını anlatmakla başlamaktadır. Bu bağlamda M. Kocobekov'un Türklerin birinci türeyiş efsanesindeki İçjinişud'un dört oğlunu Manas'ın dedesi Nogoy'un dört oğlu ile, ikinci türeyiş efsanesindeki Aşina'nın babası Nodulu Şad'ın on oğlunu Manas'ın amcası Orozdu'nun on oğluyla ilişkilendirmesi ilgi çekicidir (Kocobekov, 2014: 205). Büyüyen Manas, Altay'daki Türk boylarını birleştirerek Çin yanlısı Kalmukları bertaraf eder. Daha sonra Çin etkisi altındaki on bir boydan oluşan Uygurlara sefere çıkıp onları yener. Bize göre Manas'ın Uygurlara karşı yaptığı sefer 820-840 yılları arasındaki Yenisey Kırgızları ile Uygurlar ortasındaki savaştır. Çünkü destanda anlatılan Uygurlar on bir du-duluğa, boya ayrılmaktadır. Aynı zamanda 840 yılında Yenisey Kırgızlarına yenilen Uygurlar da başlarında tutuk (Çince du-du) bulunan on bir boydan oluşmakta idi (Kamalov, 2001: 128). Buna benzer durumlardan hareketle destanda anlatılan Uygur savaşını 840 yılındaki Kırgız-Uygur Savaşı ile ilişkilendirmek mümkündür (Useev, 2017: 103-108). Uygurları yendikten sonra Manas, Amur Nehri'nden Hazar Denizi'ne kadarki Türk boylarını birleştirerek merkezi Talas'ta bulunan büyük bir imparatorluk kurar. Ancak her zaman 
Manas Destanında Yer Alan Almambet ve Kül Çoro Ísimli Kahramanlar ile

Tarihte Yaşamış Tunyukuk ve Küli Çor Arasındaki Benzerlikler

tehlike uyandıran Çinlileri de bertaraf etmesi gerekirdi. Dolayısıyla Çin'e karş1 'Çon Kazata (Büyük Sefere)' çıkar. Çin'in merkezi Beecin'i ele geçirir. Ancak daha sonra hile ile Konurbay tarafindan yaralanır. Büyük bir savaşta Almambet, Çubak, Sırgak gibi en yakın arkadaşlarından, alplarından ayrılır. Geri çekilmek zorunda kalan Manas, Talas'a döndükten sonra vefat eder. İşte burada tarih gerçeklerine aykırı bir durum ortaya çıkmaktadır. Çünkü zamanında, netleştirirsek 745 yılında Köktürk Kağanlı̆̆ı'nı yenerek yerine kurulan Ötüken Uygur Kağanlığı'nı 840 yılında zapt eden Kırgızlar, kendilerinden öncekiler gibi olamamışlardır. Yani Köktürk ve Ötüken Uygur Kağanlıkları gibi bütün Türk boylarını birleştirememişler, Çin'i hâkimiyeti alına alarak vergi alamamışlardır. Merkezi Asya'ya hâkim olmasına, büyük bir devlet kurmasına rağmen 920 yılında Kara Kıtaylar tarafından yıkılmıştır. Bize göre işte bu durum - bütün Türk boylarını birleştirememe, Çin'i hâkimiyeti altına alamama, Kara Kıtaylara yenilme - Manas Destanı'nın ortaya çıkmasına neden olmuştur. Çünkü destanın amacı, ana konusu Kırgızları, Türk boylarını bir çatı altında birleştirmek, en önemli olayı ise Çin'i zapt etmektir. Destanlar ise her ne kadar gerçek tarihî olaylardan esinlenerek oluşsa da asıl amacı halkın tarihî tecrübesini genelleyerek ideal dünyayı, ideal kahramanları oluşturmaktır (Propp, 1999: 10).

Nüfus sayısının azlığı, Çin'in her zaman uyguladığı ikiyüzlü siyaseti ve diğer Türk boylarının Batı'ya doğru kayması sonucunda Moğolistan'a hâkim olamayan ve bu kutsal toprakları 920'lerde Kara Kitaylara birakmak zorunda kalan Kırgızlar, tarihte gerçekleştiremedikleri amaçlarını sözlü edebiyat ürününde, Manas Destanında gerçekleştirmişlerdir. Örnek olarak da Köktürk Kağanlığı'nı almışlardır. Çünkü Köktürk Kağanlığı Türk boylarını bir çatı altında birleştiren, ekonomik ve askerî bakımdan zirveye ulaşan ve en önemlisi Çin'i kendi hâkimiyet altına alan bir devletti. Zaten 840 yılında V. V. Bartold'un deyimiyle 'Büyük Kırgız Kağanlığını' kuran ve Moğolistan' daki Türk varlığının son temsilcileri olan Kırgızlar, kendilerini Türk Kağanlığının şanlı şerefli tarihinin mirasçıları olarak görmüşlerdir (Bakirov, 1997: 88). Bundan dolayı söz konusu destanın VI-X. asırlar arasındaki Eski Türk tarihini, hayatını, kültürünü yansıttığını söyleyebiliriz. Bundan dolayı Manas Destanı tarihçiler, etnograflar, kültür araştırmacıları tarafindan ele alınmalıdır. 


\section{Kaynakça}

Aalieva, A. vd. (2015). 'Manas'Sagımbay Entsiklopediyası. Bişkek.

Abdrahmanov, I. (1992). 'Uluu Manasçı Sagınbay Orozbakovdun Ömür Bayanı'. Uluu Manaçı Sagınbay, Bişkek: 59-72.

Alyılmaz, C. (2005). Orhun Yazıtlarının Bugünkü Durumu. Ankara: Kumay Yayınları.

Auezov, M. (1995). 'O Vremeni Vozniknoveniya Eposa 'Manas'. Entsiklopediçeskiy Fenomen Eposa 'Manas'. Bişkek: 149-174.

Aydın, E. (2012). 'Küli Çor Yazıtı ve Yazıtla İlgili Sorunlar Üzerine Notlar'. Dil ve Edebiyat Araştırmaları Dergisi, 5, 251-272.

Bakirov, A. (1997). İstorizm Eposa 'Manas’. Bişkek.

Bakçiev, T. A. (2014). “Manas’ Eposu cana Sostsiyalisttik İdeologiya'. Kırgız Kaganatı Türk Elderinin Orto Kılımdardagı Mamlekettüülügünün cana Madaniyatının Alkaginda, Bişkek: 395-400.

Bernştam, A. N. (1968). 'Epoha Vozniknoveniya Kirgizskogo Eposa 'Manas'. 'Manas'Geroiçeskiy Epos Kirgizskogo Naroda, Frunze:148-176.

Caynakova A ve Boronov A. (1995). 'Kül Çoro'. Manas Entsiklopediyası. I. Cilt, Bişkek: 576-579.

Ercilasun, A. B. (2002). 'Salur Kazan Kimdir'. Millî Folklor. C 7, 56, Kış 2002, 22-33.

Falev, P. A. (1968). 'Kak Stroitsya Kara-Kirgizskaya Bılina'. 'Manas'- Geroiçeskiy Epos Kirgizskogo Naroda, Frunze: 49-55.

Gömeç, S. (2000). 'İslam Öncesi Türk Tarihinin Kaynakları Üzerine’. Tarih Araştırmaları Dergisi, Cilt 20, 31, 2000, 51-92.

Gömeç, S. (2002). "Destanlarda ve Han-name'de Geçen Vezirlerin Tunyukuk ile İlgisi Olabilir mi?”. XIV. Türk Tarih Kongresi. 9 Eylül Ankara: 441-448.

Gömeç, S, (2003a). 'Türk Tarihinin Kahramanları: 17-Bilge Tunyukuk'. Orkun, 69.

Gömeç, S, (2003b). 'Türk Tarihinin Kahramanları XVI: Işbara Bilge Köl İç Çor’. Orkun, 66,35 .

Guluyev, A. (1995). 'Manas Destanı'nda Kişi Adları'. Manas Destanı ve Etkileri Uluslararası Bilgi Şöleni Bildirileri. Ankara: 117-122.

Guriev, T. A. (1983). 'İstoriçeskaya Osnova Nekotorıh Antroponimov v Osetinskom Nartovskom Epose'. Folklor i İstoriçeskaya Etnografiya, Moskova: 107-118.

Jirmunskiy, V. M. (1995). 'Vvedeniye v İzuçeniye Eposa 'Manas'. Entsiklopediçeskiy Fenomen Eposa 'Manas'. Bişkek: 85-149.

Kamalov, A. K. (2001). Drevniye Uygurı VIII-IXvv. Almat1.

Karabacak, E. (1995). Manas Destanında Ganimet Anlayışı. Bozkırdan Bağımsızlı̆̆a Manas (yay haz. Prof. Dr. Emine Gürsoy-Naskali), Ankara: Türk Dil Kurumu Yayınları.

Karalaev, S. (1960). Seytek: Manas Eposunun Üçünçü Bölügü (S. Karalaevdin Varyantı Boyunça). 4 kitep. Frunze.

Karalaev, S. (1987). Semetey, I Kitep (haz. Kırbaşev, K. ve Sarıpbekov, R.). Frunze: 1987.

Klyaştornıy, S. G. (1964). Drevnetyurkskiye Runiçeskiye Pamyatniki Kak Ístoçnik Po Ístorii Sredney Azii. Moskova.

Klyaştornıy, S. G. (1966). 'Tonyukuk - Aşide Yuançjen'. Tyurkologiçeskiy Sbornik. K Şestidesyatiletiyu A. N. Kononova. Moskova: 202-205. 
Manas Destanında Yer Alan Almambet ve Kül Çoro İsimli Kahramanlar ile

Tarihte Yașamıș Tunyukuk ve Küli Çor Arasındaki Benzerlikler

Kocobekov, M. (2014). “Manas' Eposundag1 Mamlekettik İdealdar'. Türk Tsivilizatsiyası cana Mamlekettik Saltı, Bişkek: 203-218.

Kondratyeva, T. N. (1967). Sobstvenniye Imena v Russkom Epose. Kazan.

Malov, S. E. (1959). Pamyatniki Drevnetyurkskoy Pis'mennosti Mongolii i Kirgizii. Frunze.

Mert, O. (2009). Ötüken Uygur Dönemi Yazıtlarından Tes, Tariat, Şine Us. Ankara.

Mert, O. (2015). Köli Çor Yazıtı ve Anıt Mezar Kompleksi. Erzurum.

Musaev, S. (2002). 'Manas Eposu'. Kırgız Adabiyatının Tarıhı, II. Cilt, 'Manas' cana Manasçılar (baş editör: Akmataliev, A.). Bişkek: 5-65.

Orozbakov, S. (2006). Manas: baatırdık epos. VI. kitap (haz. Musaev, Samar). Bişkek.

Orozbakov, S. (2014). Manas: baatırdlk epos. VI. ve VII. kitaplar (haz. Musaev, Samar). Bişkek.

Orozbakov, S. (2014). Manas: baatırdlk epos. VIII. ve IX. kitaplar. (haz. Musaev, Samar vd.). Bişkek.

Propp, V. Ya. (1998). Poetika Folklora. Moskova.

Propp, V. Ya. (1999). Russkiy Geroiçeskiy Epos. Moskova.

Putilov, B. N. (1971). Russkiy i Yujnoslavyanskiy Geroiçeskiy Epos. Moskova.

Reichl, K. (2014). 'The Concept of Early Kyrgyz History According to the Manaschy Jüsüp Mamay'. "Kırgız Kaganatı Türk Elderinn Orto Kılımdardagı Mamlekettüülügünün cana Madaniyatının Alkagında' Attuu El Aralık Clyındın (2013, 15-16 Kasım) Bayandamaları, Bişkek: 47-53.

Sarıpbekov, R. (1977). Almanbettin Obrazının Tarıhıy Önügüşü. Frunze.

Sarıpbekov, R. (2002). 'Balık (Bekmurat) Kumar Uulu'. Kirgız Adabiyatının Tarıhı, II. Cilt, 'Manas' cana Manasçılar (baş editör: Akmataliev, A). Bişkek: 162-169.

Tekin, T. (1994). Tunyukuk Yazıtı. Ankara.

Tekin, T. (2003). Orhon Türkçesi Grameri. İstanbul.

Tekin, T. (2008). Orhon Yazıtları. 3. baskı, Ankara.

Tolstova, L. S. (1983). 'İspol'zovaniya Fol'klora Pri İzuçenii Etnogeneza i Etnokul'turnıh Svyazey Narodov (N Sredneaziyatskom Materiyale)'. Fol'klor i Istoriçeskaya Etnografiya. Moskova: 6-22.

Troyakov, P. A. (1983). 'Analogii geroiçeskomu Eposu Tyurkoyazıçnıh Narodov v OrhonoYeniseyskih Pamyatnikah’. Folklor i İstoriçeskya Etnografiya. Moskova: 74-88.

Useev, N. (2016). ‘Manas Destanı'nda Bark Kelimesi ve Eski Türk Mezar Geleneği’. Türk Dünyası Dil ve Edebiyat Dergisi, Güz 42, 173-191.

Useev, N. (2017). “Manas' Eposundag1, Enesay Cazma Estelikterindegi cana 'Divanu Lugati't-Türktögü Uygur Cortuuldarı'. Mahmud Kaşkari-Barskaninin 'Divanu Lugati 't-Türk' Sözdügünün 940 Clldıgına Arnalgan Kırgız cana Türk Kaganattarının Tarıhına cana Madaniyatına Arnalgan V El Aralık İlimiy-Tacriybalık Clyındın (22-23 Eylül, 2017) Bayandamaları. Bişkek: 103-108.

Yıldız, N. (2015). Türk Dünyası Destancılık Geleneği ve Destanlar. Ankara. 


\section{Extended Summary}

Manas Epic contains a thousand-year epic tradition, history, culture and world view of the Turkic world in itself. Therefore, the Manas Epic can be a source for investigating the cultural phenomena, archaeological finds of the Kyrgyz people and Old Turkic tribes. Almambet and Kül Çoro in the Manas Epic have been compared with Tunyukuk and Küli Çor which are the statesmen who made a great contribution to the establishment of the Turkish Khanate. It has been found that there are gradual similarities in the between of these. For example, both Almambet who is epic hero and Tunyukuk in history were born and raised in China. Since Tunyukuk was born and raised in China, he received a good education in the Chinese capital. In the Manas epic, Almambet tells that he went to school with his father's initiative and studied for six years, studied Chinese and learned the Chinese script. Both were superior commanders of war intelligence. In his inscription, Tunyukuk states that most of the battles took place on his own offer. Almambet, which we think might be the trail of Tunyukuk in Manas Epic, has the same feature, superior war intelligence and commanding ability. He, like Tunyukuk, proposes to go on a campaign to Manas. Both of them set out to punish the Turks and passed to the side of the Turks. Yuançjen (Tunyukuk), who gained the trust of the Chinese administration, was assigned to the important region of Shanyuevo, where the majority of its people were Turks and other steppe tribes. His task was to examine the tribes under Chinese rule. The Chinese Emperor sends Yuanchjen to suppress the Turks who rebelled in Insan. However, instead of suppressing the rebellious Turks, Yuançjen moves to their side and becomes Ilteriş's best friend, advisor and commander. Takes the name of Turkish Tunyukuk. Almambet in the epic sets out to punish the Turks who attacked a region of China. During his expedition to the Turks in Altai, he meets the Kazakh hero, Kökçö. He learned Islam from him and later on the side of the Turks. Therefore, the passing of Tunyukuk and Almambet in the epic to the Turks has a similar motive. Based on these similarities between Almambet and Tunyukuk, it is possible to argue that Almambet in the epic may be a trace of Tunyukuk, which is very important in Turkish history. At least the personality of Almambet is certain to take into account some of the characteristics of Tunyukuk, who lived in history.

The names of Kuli Chor who lived in history and Kul Choro in the Manas Epic are the same. A. Caynakova and A. Boronov stated that the name of Kul Choro could not be explained by the Kyrgyz Turkish data and that there was no doubt that it was an old Turkish person name. And both of them are clerics for the son of the ruler. Kul Choro in the epic is the son of Almambet a Chinese hero, the closest friend of Manas, who later adopted Islam. S. Gömeç thinks that Kol İch Çor / Kuli Chor is a close relative of Tunyukuk which is likened to Almambet by us. Therefore, it is claimed that the historical person Küli Çor preserved the traces in the personality of the Kül Çoro in the Manas Epic. The reason for this is related to the history of the Old Turkish between the IX-X $\mathrm{X}^{\text {th }}$ centuries. As it is known, in 840, the Kyrgyzs ruled Central Asia and the holy Ötüken by eliminating the Uighurs. However, due to the small number of the population, China's two-sided politics 
Manas Destanında Yer Alan Almambet ve Kül Çoro Ísimli Kahramanlar ile Tarihte Yaşamış Tunyukuk ve Küli Çor Arasındaki Benzerlikler

and the shift of other Turkish tribes towards the West, the Kyrgyz did not dominate Mongolia and had to leave these holy lands to the Kara Kytais in the 920s. They expressed their aims which they could not realize in history in oral literature, in Manas Epic. They took Köktürk Khanate as an example. Because the Köktürk Khaganate was a state that united the Turkish tribes under one roof, reached the summit in economic and military terms, and most importantly took China under its rule. The Kyrgyz people who established the 'Great Kyrgyz Khaganate' in the words of V. V. Bartold in 840 and who were the last representatives of the Turkish presence in Mongolia, regarded themselves as the heirs of the glorious history of Turkish Khaganate. Because of this, we can say that Manas Epic reflects the history, life and culture of the Old Turk between the VI- ${ }^{\text {th }}$ centuries. Therefore, the epic of Manas should be handled by historians, ethnographers and cultural researchers. 